\title{
Evaluation of the Efficacy of Tenofovir in Chronic Hepatitis B Patients Unresponsive to Lamivudine
}

\author{
Lamivudine Yanıtsız Kronik Hepatit B Hastalarında Tenofovir Cevabının Değerlendirilmesi
}

\author{
Sami ÇIFÇI1, Yusuf KAYHAN2, Gökhan GÜNGÖR3, Murat BIYIK1, Mehmet ASIL1, Hüseyin ATASEVEN1, \\ Ali DEMIR1
}

${ }^{1}$ Necmettin Erbakan University Faculty of Medicine, Department of Gastroenterology, Konya, Turkey

${ }^{2}$ Amasya University Sabuncuoğlu Şerefeddin Training and Research Hospital, Clinic of Gastroenterology, Amasya, Turkey

${ }^{3}$ Konya Training and Research Hospital, Clinic of Gastroenterology, Konya, Turkey

\begin{abstract}
Objective: Chronic hepatitis B virus (HBV) infection is a global health problem and persistent viremia is associated with increased morbidity and mortality. The main goal of hepatitis B treatment is to suppress HBV replication permanently and, antiviral resistance is a major problem against viral suppression. Tenofovir is a potent antiviral drug with no reported resistance so far. There are inadequate data regarding response to tenofovir in chronic hepatitis B patients with lamivudine failure in Turkish population. The present study was conducted to evaluate response of tenofovir in patients with lamivudine failure.

Materials and Methods: A total of 48 adult patients with chronic hepatitis $B$, who have received lamivudine for at least 6 months and switched to tenofovir due to lamivudine failure were investigated retrospectively. HBV DNA levels, alanine aminotransferase (ALT) levels and serum creatinine levels were evaluated before and after tenofovir treatment and also hepatitis $B$ e antigen ( $\mathrm{HBeAg}$ ) seroconversion and hepatitis $B$ surface antigen ( $\mathrm{HBsAg}$ ) loss rates were evaluated.

Results: Viral suppression rates (HBV DNA $<400$ copies/ml) were found to be $89 \%$ on the $6^{\text {th }}$ month and $94 \%$ on the $12^{\text {th }}$ month of tenofovir treatment. The mean follow-up time was 21.4 months and totally $96 \%$ of patients were found to achieve viral suppression with tenofovir. ALT normalization rates were found to be $60 \%$ on the first year of treatment with tenofovir and overall ALT normalization rate was $90 \%$. HBeAg seroconversion was detected in $42 \%$ of $\mathrm{HBe}$ antigen $(+)$ patients after the first year of tenofovir treatment and disappearance of HBsAg was observed in none of the patients. Conclusion: Tenofovir treatment is an effective and well-tolerated therapeutic option in chronic hepatitis B resistant to lamivudine. Keywords: Hepatitis B, lamivudine, drug resistance, tenofovir
\end{abstract}

ÖZ

Amaç: Kronik hepatit B virüs (HBV) enfeksiyonu global bir sağlık problemi olup artmış morbidite ve mortalite ile ilişkilidir. Tedavideki ana hedef HBV replikasyonunu sürekli bir şekilde baskılayabilmektir. Ancak antiviral direnç kalıcı supresyon önünde ciddi bir engel teşkil etmektedir. Ülkemizde lamivude yanıtsız hastalarda tenofovire olan yanıtının değerlendirilmesi ile ilgili yeterli verilerin olmaması nedeniyle, bu çalışmanın yapılması planlanmıştır.

Gereç ve Yöntemler: On sekiz yaşından büyük, en az 6 ay lamuvudin kullanmış ve direnç tespit edildikten sonra tenofovir başlanmış 48 hasta çalışmaya alındı. Hastaların tenofovir öncesi ve sonrası HBV DNA düzeyleri, hepatit $B$ e antijen (HBeAg) serokonversiyonu ve hepatit B yüzey antijeni (HBsAg) kaybı oranları retrospektif olarak incelendi.

Bulgular: Lamivudin direnci sonrası tenofovir alan hastalarda viral supresyon (HBV DNA <400 kopya/ml) tedavinin 6. ayında \%89, 12. ayında $\% 94$ ve ortalama 21,4 aylık tedavi sonrası ise $\% 96$ oranında saptandı. Alanin aminotransferaz normalizasyonunun tedavinin birinci yılında \%60 ve 21,4 aylık izlem süresinin sonunda ise $\% 90$ oranında sağlandığı görüldü. Tedavinin birinci yılında $\mathrm{HBeAg}$ kaybı \%42 hastada tespit edildi. HBsAg kaybı izlem periyodu boyunca hiçbir hastada saptanmadı.

Sonuç: Lamivudine yanıtsız kronik hepatit B hastalarında tenofovir etkili ve iyi tolere edilebilen bir tedavi seçeneğidir.

Anahtar Kelimeler: Hepatit B, lamivudin, ilaç direnci, tenofovir 


\section{Introduction}

Chronic hepatitis B virus (HBV) infection is a global health problem and persistent viremia is associated with increased morbidity and mortality. It is estimated that approximately 400 million people worldwide have chronic HBV infection, and more than 0.5-1 million people die due to complications of HBVrelated chronic liver disease each year (1). Death may result from HBV-related end-stage liver disease or hepatocellular carcinoma (HCC). HBV-associated chronic liver disease and HCC accounts for $5-10 \%$ of all liver transplantations. In a nationwide study, it has been stated that the reported prevalence of hepatitis $B$ surface antigen (HBsAg) positivity in Turkey was 4\% (2).

Standard interferon alpha-2a and $2 \mathrm{~b}$, pegylated interferon alpha-2a and 2b, lamivudine, adefovir, entecavir, tenofovir and telbivudine are the drugs available in Turkey approved for the treatment of chronic hepatitis B. Resistance is an important problem for oral antiviral drugs and the likelihood of drug resistance increases with time. Reported antiviral resistance rates for lamivudine, adefovir, telbuvidine and entecavir are $65 \%, 15 \%, 17 \%$ and $1.2 \%$, respectively $(3,4,5,6)$. Resistance against tenofovir has not been reported to date yet (7).

Lamivudine was widely used in the past for the treatment of chronic hepatitis B in Turkey due to national health policies, therefore, resistance to lamivudine is an important problem. Tenofovir is an effective treatment option in case of lamivudine resistance and data concerning the effect of this drug in patients with resistance to lamivudine in Turkish population is inadequate. Thus, we aimed to conduct this study to evaluate the efficacy of tenofovir in lamivudine-resistant chronic hepatitis $B$ patients in the Turkish population.

\section{Materials and Methods}

This study was conducted in a retrospective manner. Chronic hepatitis B patients with lamivudine failure, who received at least 6 months of tenofovir therapy and attended the gastroenterology clinic at Necmettin Erbakan University Meram Faculty of Medicine between January 2008 and June 2012, were enrolled in the study. All patients were HBsAg-positive for at least 6 months with high transaminase levels (alanine amino transferase (ALT) at least 2-fold greater than the upper limit of normal) and detectable HBV DNA levels before starting lamivudine treatment and lamivudine failure was defined as (i) incomplete virologic response to lamivudine treatment (HBV DNA $>400$ copy/mL after 6 months of lamivudine treatment) or emergence of virologic resistance detected with virological breakthrough (at least 1 log increase in HBV DNA level after an initial response to lamivudine treatment).

A total of 48 patients fulfilled the criteria and were taken into the study. Demographic characteristics of the patients such as age, gender as well as duration of hepatitis B infection and concomitant chronic diseases, antiviral therapies and treatment duration, and routes of contamination were noted from patient records. Laboratory findings, including complete blood count, routine serum biochemistry tests including liver transaminases and serum urea-creatinine levels were performed on a monthly basis and HBV DNA levels were obtained at 3-month intervals.
Hepatic ultrasonography of the patients were also evaluated in terms of liver size, hepatosteatosis, presence of parenchymal heterogeneity or any possible mass lesions at the beginning of treatment and also every 6 months. Histopathological findings in liver biopsies were considered in terms of histologic activity index (HAl) and fibrosis.

HBV DNA levels were analyzed in the microbiology laboratory at our hospital. DNA extraction was performed with AmpliPrep, amplification was performed using Cobas Tagman ${ }^{\circledR}$ 48 Analyzer, and measurement was performed by real-time polymerase chain reaction (PCR). The brand of the devices was Roche Diagnostic (Mannheim, Germany) and measurable HBV DNA values ranged between 20 and $1.7 \times 10^{8} \mathrm{IU} / \mathrm{mL}$. HBsAg, hepatitis B surface antibody (anti-HBs), hepatitis B e antigen $(\mathrm{HBeAg})$ and hepatitis $\mathrm{B}$ e antibody (anti-HBe) were studied by chemiluminescence method (Abbott diagnostic, USA). Routine serum biochemistry including aspartate aminotransferase (AST), ALT and creatinine levels were measured using routine automatic analyzers.

\section{Results}

Of the 48 patients included in the study, 29 (60.4\%) were male and 19 (39.6\%) were female. The mean age of the patients was $51.3 \pm 11.1$ years. The mean age of the males was $50.4 \pm 13.2$ years (range: $25-75$ ) and the mean age of the females was $52.7 \pm 6.9$ years (range: $39-66$ ). Demographic and clinical characteristics of the patients are given in Table 1.

The mean duration of lamivudine therapy was $37.2 \pm 25.4$ months (7-108 months) and the mean duration of tenofovir therapy was $21.4 \pm 7.3$ months (12-36 months). Eleven $(22.9 \%)$ patients received tenofovir for 12 months, 27 (56.3\%) patients received tenofovir for 12 to 24 months, and 10 (20.8\%) received tenofovir for 24 to 36 months. At the beginning of tenofovir treatment, 41 (85.4\%) patients were $\mathrm{HBeAg}$-negative and 7 (14.6\%) patients were HBeAg-positive. HBeAg seroconversion was detected in $3(42 \%)$ patients after treatment with tenofovir.

In 10 patients, ALT levels were elevated prior to treatment with tenofovir. ALT normalization was achieved in 6 (60\%) of these patients within 1 year of the tenofovir treatment and, 9 (90\%) of 10 patients were found to be ALT normal after a mean 21.4 months of tenofovir therapy. In 47 (98\%) of 48 patients enrolled in the study, ALT levels were normal after tenofovir treatment. No increase was observed in creatinine levels after a mean 21.4 months of tenofovir therapy.

The mean logarithmic HBV DNA (copy/mL) levels at the baseline (before starting tenofovir treatment) and on the $6^{\text {th }}$ month and $12^{\text {th }}$ month of treatment were $4.6 \pm 1.4 \log _{10}$ $1.5 \pm 1.3 \log _{10}$ and $1.4 \pm 1.3 \log _{10}$, respectively. There was a statistically significant decrease in HBV DNA levels on the $12^{\text {th }}$ month of treatment compared to pretreatment baseline levels $(p<0.001)$. In the $6^{\text {th }}$ month of the tenofovir treatment, $43(89 \%)$ patients achieved HBV DNA levels to be suppressed below the measurable level ( $<400 \mathrm{copy} / \mathrm{mL}$ ) and HBV DNA levels were below the measurable level in 45 (94\%) patients in the $12^{\text {th }}$ month of treatment. Overall in 46 (98\%) patients, HBV DNA levels were below the measurable levels after tenofovir treatment (mean treatment time: $21.4 \pm 7.3$ months). 


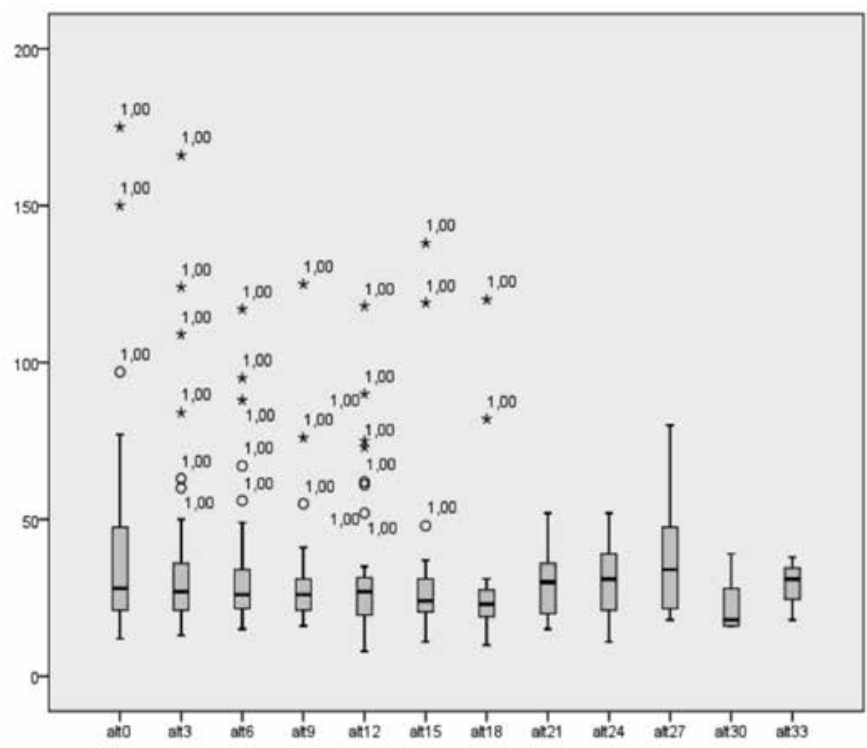

Figure 1. Distribution of mean alanine aminotransferase (U/L) levels of the patients on tenofovir therapy

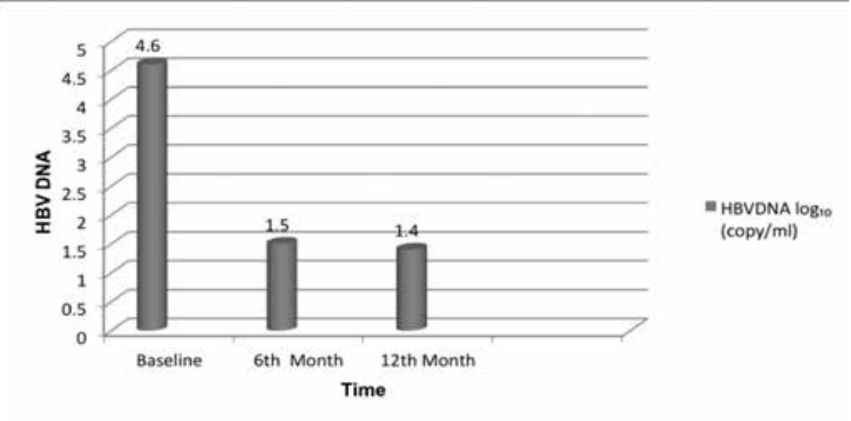

Figure 2. Hepatitis B virus DNA levels of the patients receiving tenofovir $\left[\log _{10}(\right.$ copy $\left./ \mathrm{mL})\right]$

\section{Discussion}

The goal of treatment of chronic hepatitis B infection is to increase survival and the quality of life by preventing progression of the disease to cirrhosis, end-stage liver disease, HCC and, eventually, death. Permanent suppression of viral replication is the key factor to achieve this goal. Inhibition of viral replication with possible accompanying histological improvement reduces progression to cirrhosis and HCC in non-cirrhotic patients and, $\mathrm{HCC}$ risk is also reduced to some extent in cirrhotic patients as well. Antiviral resistance is an important issue in patients receiving oral antiviral drugs and switching to another oral antiviral agent or addition of a second antiviral drug is recommended. Since crossreaction to entecavir is a problem, tenofovir is recommended in lamivudine resistance (8).

Tenofovir is a potent antiviral drug used for the treatment of chronic hepatitis B. In a study conducted by Idilman et al., it was shown that long-term tenofovir treatment effectively suppressed viral replication in real-life setting in treatment-naive patients (9). Tenofovir has also been found to be effective and well tolerated in patients resistant to other antiviral drugs $(10,11,12)$. Van Bömmel et al. (13) conducted a retrospective multi-center study of 131 patients to assess the long-term efficacy of tenofovir monotherapy in patients experiencing resistance to lamivudine-adefovir. They have reported that in $79 \%$ of patients, HBV DNA levels were below the measurable levels after a mean duration of 23 months of tenofovir therapy. The mean pretreatment HBV DNA level was $7.6 \pm 1.5 \log _{10}$ and viral suppression was achieved in all (100\%) patients with lamivudine resistance. In another study, Baran et al. (11) have reported that tenofovir at $300 \mathrm{mg} /$ day as monotherapy or add-on therapy was safe and well-tolerated option for hepatitis $B$ treatment and tenofovir treatment was equally effective in treatment-naive or lamivudine-resistant patients in the Turkish population.

Viral suppression rates in our study were consistent with the literature. Forty-three (89\%) of our patients achieved viral

\begin{tabular}{|l|r|}
\hline Table 1. Demographic and clinical characteristics of the patients & Total number of patients $\mathbf{n = 4 8}$ \\
\hline Characteristic & $51.3 \pm 11.1(25-75)$ \\
\hline Age, year (mean) & $29 / 19$ \\
\hline Gender (male/female) & 3 (14.6\%) \\
\hline HBeAg positivity, $\mathrm{n}$ (\%) & $37.2 \pm 25.4(7-108)$ \\
\hline Duration of lamivudine treatment, mean (month), (range) & $21.4 \pm 7.3(12-36)$ \\
\hline Duration of tenofovir treatment, mean (month), (range) & $4.6 \pm 1.4(2.7-8.8)$ \\
\hline HBV DNA (mean, log 10 copy/mL) (range) & $58.0 \pm 105.7(12-677)$ \\
\hline ALT, mean U/L (range) & $55.9 \pm 154.3(17-1086)$ \\
\hline AST, mean U/L (range) & $13.6 \pm 2.2(4.9-17.2)$ \\
\hline Hemoglobin, mean g/dL (range) & $231.3 \pm 67.5(64-427)$ \\
\hline Platelet, mean 103 u/L & $0.8 \pm 0.4(0.4-3.7)$ \\
\hline Creatinine, mean mg/dL (range) & \\
\hline
\end{tabular}

HBeAg: Hepatitis B e antigen, HBV: Hepatitis B virus, ALT: Alanine aminotransferase, AST: Aspartate aminotransferase 
suppression below the measurable values $(<400$ copy $/ \mathrm{mL})$ at the $6^{\text {th }}$ month of treatment and overall viral suppression rate was $96 \%$ after a mean treatment duration of $21.4 \pm 7.3$ months. 2 (4\%) patients failed to achieve virologic suppression with tenofovir therapy. Taking into account that no viral resistance with tenofovir has been reported in the literature up to date, patients were re-questioned and were found to be noncompliant with the treatment. The results of our study also showed that ALT normalization was achieved in $60 \%$ of patients at the end of the $1 \mathrm{st}$ year. ALT levels were within the normal range in $98 \%$ of all patients at the end of the follow-up period and ALT exacerbation was not observed in any of the patients during tenofovir therapy.

Tenofovir-associated nephrotoxicity has been reported at a rate of $4 \%$ in HIV-positive patients receiving tenofovir therapy (14). This adverse event has not been detected at considerable levels yet in chronic HBV patients (15). However, it is worth to be noted that tenofovir has been used for HIV treatment for a much longer time and its usage in chronic hepatitis B is relatively new. In the present study, an increase in creatinine level was not detected in any patients during tenofovir therapy.

In conclusion, tenofovir is an effective and well-tolerated therapeutic option in patients with chronic hepatitis B in whom lamivudine treatment is unsuccessful due to primary or secondary resistance. Further studies with larger patient populations and longterm follow-up periods are needed to address histological effects, long-term reliability and potential adverse effects of tenofovir treatment in these patients.

\section{Authorship Contributions}

Ethics Committee Approval: The study were approved by the Necmettin Erbakan University of Local Ethics Committee, Informed Consent: Consent form was filled out by all participants, Concept: Sami Çifçi, Yusuf Kayhan, Ali Demir, Design: Sami Çifçi, Yusuf Kayhan, Ali Demir, Data Collection or Processing: Sami Çifçi, Yusuf Kayhan, Gökhan Güngör, Murat Bıyık, Mehmet Asil, Analysis or Interpretation: Yusuf Kayhan, Murat Bıyık, Gökhan Güngör, Mehmet Asil, Hüseyin Ataseven, Literature Search: Sami Çifçi, Yusuf Kayhan, Gökhan Güngör, Mehmet Asil, Writing: Sami Çifçi, Yusuf Kayhan, Murat Bıyık, Mehmet Asil, Peer-rewiev: External and Internal peer-reviewed, Conflict of Interest: No conflict of interest was declared by the authors, Financial Disclosure: The authors declared that this study has received no financial support.

\section{References}

1. Kao JH, Chen DS. Global control of hepatitis B virus infection. Lancet Infect Dis. 2002;2(7):395-403.

2. Tozun N, Ozdogan $\mathrm{O}$, Çakaloğlu Y, Idilman R, Karasu Z, Akarca $U$ et al. Nationwide Prevalence Study and Risk Factors for Hepatitis A, B, C and D Infections in Turkey. The 61st Annual Meeting of the American Association for the Study of Liver Diseases: The Liver Meeting ${ }^{\circledR}$ 2010. October 29November 2 2010, Boston USA, Poster No: 789, Hepatology Vol 52 S1:697 A.
3. Lok AS, Lai CL, Leung N, Yao GB, Cui ZY, Schiff ER, Dienstag JL, Heathcote EJ, Little NR, Griffiths DA, Gardner SD, Castiglia $M$. Long-term safety of lamivudine treatment in patients with chronic hepatitis B. Gastroenterology. 2003;125(6):1714-1722.

4. Marcellin P, Chang TT, Lim SG, Sievert W, Tong M, Arterburn S, Borroto-Esoda K, Frederick D, Rousseau F. Long-term efficacy and safety of adefovir dipivoxil for the treatment of hepatitis $B$ e antigen-positive chronic hepatitis B. Hepatology. 2008;48:750758.

5. Liaw YF1, Gane E, Leung N, Zeuzem S, Wang Y, Lai CL, Heathcote EJ, Manns M, Bzowej N, Niu J, Han SH, Hwang SG, Cakaloglu Y, Tong MJ, Papatheodoridis G, Chen Y, Brown NA, Albanis E, Galil K, Naoumov NV; GLOBE Study Group. 2-Year GLOBE trial results: telbivudine is superior to lamivudine in patients with chronic hepatitis B. Gastroenterology. 2009;136(2):486-495.

6. Tenney DJ, Rose RE, Baldick CJ, Pokornowski KA, Eggers BJ, Fang J, Wichroski MJ, Xu D, Yang J, Wilber RB, Colonno RJ. Long-term monitoring shows hepatitis $B$ virus resistance to entecavir in nucleoside-naïve patients is rare through 5 years of therapy. Hepatology. 2009;49(5):1503-1514.

7. Kitrinos KM, Corsa A, Liu Y, Flaherty J, Snow-Lampart A, Marcellin P, Borroto-Esoda K, Miller MD. No detectable resistance to tenofovir disoproxil fumarate after 6 years of therapy in patients with chronic hepatitis B. Hepatology. 2014;59(2):434-442

8. European Association For The Study Of The L. EASL Clinical Practice Guidelines: Management of chronic hepatitis B virus infection. J Hepatol. 2012;57(1):167-185.

9. Idilman R, Gunsar F, Koruk M, Keskin O, Meral CE, Gulsen $M$, Elhan $A H$, Akarca US, Yurdaydin C. Long-term entecavir or tenofovir disoproxil fumarate therapy in treatment-naïve chronic hepatitis B patients in the real-world setting. J Viral Hepat. 2015;22(5):504-510.

10. Kuo A, Dienstag JL, Chung RT. Tenofovir disoproxil fumarate for the treatment of lamivudine-resistant hepatitis B. Clin Gastroenterol Hepatol. 2004;2(3):266-272.

11. Baran B, Soyer OM, Ormeci AC, Gokturk S, Evirgen S, Bozbey HU, Akyuz F, Karaca C, Demir K, Besisik F, Onel D, Gulluoglu M, Badur S, Kaymakoglu S. Efficacy of tenofovir in patients with Lamivudine failure is not different from that in nucleoside/ nucleotide analogue-naive patients with chronic hepatitis $B$. Antimicrob Agents Chemother. 2013;57(4):1790-1796.

12. Basarır I, llikhan S, Harmandar F, Soyaltın UE, Aydemir S, Ustundag $Y$. Assessment of treatment responses in patients with chronic active hepatitis B. Akademik Gastroenteroloji Dergisi 2013:12(2):58-65

13. Van Bommel $F$, de Man RA, Wedermeyer $H$, Deterding $K$, Petersen J, Buggisch P, Erhardt A, Hüppe D, Stein K, Trojan J, Sarrazin C, Böcher WO, Spengler U, Wasmuth HE, Reinders JG, Möller B, Rhode P, Feucht HH, Wiedenmann B, Berg T. Longterm efficacy of tenofovir monotherapy for hepatitis B virusmonoinfected patients after failure of nucleoside/nucleotide analogues. Hepatology. 2010;51(1):73-80.

14. Antoniou T, Raboud J, Chirhin S, Yoong D, Govan V, Gough K, Rachlis A, Loutfy M. Incidence of and risk factors for tenofovirinduced nephrotoxicity: a retrospective cohort study. HIV Med. 2005;6(4):284-290.

15. Khungar V, Han SH. A Systematic Review of Side Effect of Nucleoside and Nucleotide Drugs Used for Treatment of Chronic Hepatitis B. Curr Hepat Rep. 2010;9(2):75-90. 